\title{
PRESERVASI KOLEKSI BAHAN PUSTAKA AKIBAT BENCANA ALAM DI PERPUSTAKAAN SDN KUDANG TASIKMALAYA
}

\author{
${ }^{1}$ Eka Dian Oktaningrum, ${ }^{2}$ Fitri Perdana \\ ${ }^{1}$ Kepala Perpustakaan STAI Tasikmalaya, ${ }^{2}$ Program Studi Ilmu Perpustakaan Unpad \\ 1dianoktaningrum206@gmail.com, ${ }^{2}$ peet_lithuania79@ymail.com
}

ABSTRACT - Elementary School Library Kudang Manonjaya Tasikmalaya as one of the rescue efforts of library materials from further damage by appropriate methods commonly referred to preservation activities. This study used a qualitative approach, with greater emphasis in the way of description reveal phenomena experienced by study subjects. The subject of research that SDN library Kudang Manonjaya District of Tasikmalaya regency. The object studied is the preservation process before, during and after the incident occurrence earthquake. Results from this study indicate that preservation before disaster events has not been properly implemented among others is the establishment of natural disaster prevention planning team. At the time of the incident, Tasikmalaya earthquake of 2009 occurred at 14:55:21 pm, at which time the teaching and learning activities in SDN Kudang been completed, so that no one who was on the scene. Under these conditions of preservation at the time of earthquake occurrence is only carried out on goods that are at risk of more severe damaged. Preservation after earthquake occurrence has been able to be implemented properly. Rescue efforts of library materials held in SDN Kudang post events Tasikmalaya earthquake of 2009 is to evacuate the library materials, identify the types of library materials are damaged, then the restoration, cleaning, tightening the cover, patch, connect, and re binding.

Keywords: Preservation, collection, earthquakes

ABSTRAK - Perpustakaan Sekolah Dasar Negeri Kudang Manonjaya Tasikmalaya merupakan salah satu sekolah yang terkena bencana alam, sebagai salah satu upaya penyelamatan bahan pustaka dari kerusakan yang lebih parah maka dilakukanlah kegiatan preservasi. Penelitian ini menggunakan pendekatan kualitatif, dengan lebih menekankan cara deskripsi dalam mengungkapkan fenomena yang dialami oleh subyek penelitian. Adapun yang menjadi subyek penelitian yaitu perpustakaan SDN Kudang Kecamatan Manonjaya Kabupaten Tasikmalaya. Objek yang dikaji adalah proses preservasi sebelum, saat kejadian dan setelah kejadian bencana alam gempa bumi. Hasil dari penelitian ini menunjukkan bahwa preservasi sebelum kejadian bencana belum dilaksanakan dengan baik diantaranya adalah belum dibentuknya tim perencanaan pencegahan bencana alam. Pada saat kejadian, Gempa Bumi Tasikmalaya Tahun 2009 terjadi pada pukul 14:55:21WIB, dimana pada saat tersebut kegiatan belajar mengajar di SDN Kudang sudah selesai, sehingga tidak ada orang yang berada di lokasi. Dengan kondisi tersebut preservasi pada saat kejadian gempa bumi hanya dilakukan pada barang-barang yang beresiko rusak lebih parah. Preservasi setelah kejadian gempa bumi telah dapat dilaksanakan dengan baik. Upaya penyelamatan bahan pustaka yang dilaksanakan di SDN Kudang paska kejadian gempa bumi Tasikmalaya Tahun 2009 adalah dengan cara mengevakuasi bahan pustaka, mengidentifikasi jenis bahan pustaka yang mengalami kerusakan, kemudian dilakukan pemulihan, pembersihan, pengencangan sampul, menambal, menyambung, dan penjilidan ulang.

Kata kunci: Preservasi, koleksi, gempa bumi

\section{PENDAHULUAN}

Bencana yang cukup sering terjadi di Indonesia adalah Gempa Bumi. Hal ini 
diakibatkan oleh letak geografis daerah Indonesia yang berada pada pertemuan tiga lempeng tektonik yang saling bergerak satu sama lainnya, menjadikan sebagai salah satu penyebab Indonesia sering dilanda bencana alam sehingga tidak heran apabila ada yang menjuluki Indonesia sebagai supermarket of disaster. Dampak dari bencana alam akan dirasakan oleh semua yang terkena bencana termasuk perpustakaan. Sebagai upaya penyelamatan bahan pustaka dari kerusakan yang lebih parah sebagai akibat dari bencana alam, maka diperlukan adanya penanganan yang baik sehingga koleksi dapat diselamatkan. Untuk itu sebagai upaya penyelamatan bahan pustaka di butuhkan suatu metode yang tepat yang biasa disebut dengan kegiatan preservasi (Sugiharto, 2010). Preservasi berasal dari kata preserve atau to preserve adalah salah satu aspek dari menajemen di perpustakaan, dimana dalam sebuah perpustakaan mengenal 4 aspek penting, yaitu: berkaitan dengan bagaimana mengumpulkan bahan pustaka, pengolahan, penyebarluasan dan pelestarian/preservasi.

Secara umum, bencana dapat dikategorikan menjadi dua jenis, yaitu bencana alam dan bencana yang disebabkan oleh manusia. Bencana alam adalah bencana yang diakibatkan oleh alam, seperti gempa bumi, banjir, tsunami, atau gunung meletus. Sementara itu, bencana yang diakibatkan oleh manusia antara lain perusakan bahan pustaka (vandalism) (Sitepu, Armansyah, Saary \& Rahayu). Kedua jenis bencana tersebut memiliki konsekuensi yang sama yaitu adanya dampak yang ditimbulkan berupa kerusakan sarana dan prasarana. Disaster (bencana) didefinisikan sebagai suatu kejadian yang waktu terjadinya tidak dapat diprediksi dan dapat bersifat sangat merusak. Pengertian ini mengenali sebuah kejadian yang memiliki empat faktor utama, yaitu datang tiba-tiba, tidak diharapkan, dapat sangat merusak, dan kurang adanya perencanaan. Bencana terjadi dengan frekuensi yang tidak menentu kapan terjadinya dan akibat yang ditimbulkannya bisa terjadi sangat merusak bagi mereka yang tidak mempersiapkan diri terhadap kemungkinan timbulnya bencana. Dari pengertian tersebut dapat dipahami bahwa bencana alam sampai saat ini belum dapat diprediksi kapan dan dimana, sehingga kita tidak dapat melakukan persiapan dalam menghadapi dampak yang akan ditimbulkan oleh bencana tersebut.

Pada tahun 2009 Tasikmalaya di guncang gempa bumi yang cukup besar berkekuatan 7,3 SR yang mengakibatkan sarana dan prasarana mengalami kerusakan, mulai kerusakan ringan sampai kerusakan yang berat. Perpustakaan SDN Kudang Kecamatan Manonjaya Kabupaten Tasikmalaya merupakan salah satu bangunan yang terkena dampak dari gempa 
tersebut. Sebagian besar bangunan mengalami kerusakan khususnya pada bagian dinding dan atap sehingga mengakibatkan koleksi yang ada di perpustakaan mengalami kerusakan yang cukup parah. Kerusakan bahan pustaka ini mencapai kurang lebih $75 \%$ dari jumlah koleksi yang ada. Sebagai upaya penyelamatan bahan pustaka dari kerusakan yang lebih parah sebagai akibat dari bencana alam, maka diperlukan adanya penanganan yang baik sehingga koleksi dapat diselamatkan. Untuk itu sebagai upaya penyelamatan bahan pustaka di butuhkan suatu metode yang tepat yang biasa disebut dengan kegiatan preservasi. Preservasi berasal dari kata preserve atau to preserve adalah aspek dari sebuah menajemen perpustakaan. Pelestarian (preservation) menurut International Federation of Library Association (IFLA) mencakup semua aspek usaha melestarikan bahan pustaka, keuangan, ketenagaan, metode dan teknik, serta penyimpanannya (Martoatmodjo, 2009). Sementara itu Ballofet and Hille mendeskripsikan preservasi sebagai kegiatan yang mencakup kegiatan fisik dokumen dan informasi yang terkandung di dalamnya, meliputi penyusunan kembali, penempatan ulang, dan penggunaan dari wadah atau tempat pelindung yang bertujuan memperluas akses untuk informasi yang kemungkinan bisa hilang karena halaman yang hilang, atau karena dokumen yang rusak (Ballofet \& Hille, 2005).

Menurut pengertian tersebut, makna preservasi atau perawatan bahan pustaka secara umum adalah kegiatan melestarikan, memelihara dan memperbaiki bahan pustaka dari kehancuran, kerapuhan karena manusia, serangga, debu, cahaya dan lingkungan alam. Kegiatan preservasi atau aktivitas yang dilakukan pada persevasi tergantung pada kondisi, persoalan dan kemungkinan yang dapat dikembangkan dalam upaya pemeliharaan lebih lanjut. Pada dasarnya preservasi adalah upaya mempertahankan sumber daya kultural dan intelektual agar dapat digunakan sampai batas waktu yang selama mungkin. Sebagaimana diungkapkan diatas bahwa dalam upaya penyelamatan bahan pustaka dari kerusakan yang lebih parah sebagai akibat dari bencana alam, maka diperlukan adanya penanganan yang baik sehingga koleksi dapat diselamatkan, dalam hal ini penanganan koleksi akibat bencana perlu dilakukan dengan prosedur/tata cara penanganan yang baik, sehingga koleksi dapat diselamatkan dengan baik.

Kerusakan yang cukup parah yang dialami oleh Perpustakaan SD Negeri Kudang Manonjaya sebagai akibat Bencana Alam Gempa Bumi tersebut memerlukan adanya penanganan sesuai prosedur 
preservasi yang baik sehingga koleksi yang ada dapat diselamatkan dan dimanfaatkan kembali oleh pemustaka, dari hal ini penulis merasa tertarik untuk meneliti "Bagaimana proses preservasi koleksi akibat bencana alam gempa bumi di Perpustakaan SD Negeri Kudang Kecamatan Manonjaya Kabupaten Tasikmalaya?"

\section{TINJAUAN PUSTAKA}

\section{Pengertian Perpustakaan}

Dalam pandangan umum, perpustakaan dipahami sebagai sebuah tempat atau gedung dimana didalamnya terdapat deretan buku-buku dan bahan bacaan lainnya yang dapat dimanfaatkan oleh para pembacanya. Pemahaman tersebut cukup beralasan, dimana perpustakaan didefinisikan oleh Sulistyo Basuki sebagai:

a. Kumpulan buku dan materi perpustakaan lainnya yang disimpan untuk keperluan bacaan, belajar dan konsultasi.

b. Sebuah tempat, gedung, ruang atau sejumlah ruang yang diatur untuk menyimpan dan menggunakan koleksi buku (Basuki, 2010).

Dari definisi tersebut dapat dipahami bahwa perpustakaan sebagai kumpulan buku dan materi lainnya yang disimpan untuk keperluan bacaan, belajar dan konsultasi pada sebuah tempat, gedung atau sejumlah ruangan yang diatur sehingga memudahkan bagi para pengguna. Definisi lain mengnai perpustakaan dikemukakan oleh ALA (The American Library Association) dimana ALA menggunakan istilah perpustakaan untuk suatu pengertian yang luas yaitu termasuk pengertian "pusat media, pusat belajar, pusat sumber pendidikan, pusat informasi, pusat dokumentasi dan pusat rujukan“. Sedangkan menurut Keputusan Presiden RI nomor 11, disebutkan bahwa "Perpustakaan merupakan salah satu sarana pelestarian bahan pustaka sebagai hasil budaya dan mempunyai fungsi sebagai sumber informasi ilmu pengetahuan, teknologi dan kebudayaan dalam rangka mencerdaskan kehidupan bangsa dan menunjang pelaksanaan pembangunan nasional.

Adapun pengertian perpustakaan sekolah menurut Sulistyo Basuki adalah:

"Perpustakaan yang berada pada lembaga pendidikan formal di lingkungan pendidikan dasar dan menengah yang merupakan bagian integral dari kegiatan sekolah yang bersangkutandan merupakan pusat sumber belajar untuk mendukung tercapainya tujuan pendidikan sekolah yang bersangkutan” (Basuki, 2010).

Menurut pengertian diatas dapat dipahami bahwa perpustakaan sekolah 
merupakan bagian yang tidak terpisahkan dan harus menjadi bagian penting dari sekolah sehingga tujuan pendidikan di sekolah yang bersangkutan dapat tercapai. Hal ini juga menunjukkan bagaimana perpustakaan seharusnya bisa berperan sebagai komponen penting dalam keberhasilan proses pendidikan dan kegiatan pembelajaran di sekolah.

\section{Pengertian Preservasi}

Preservasi bahan pustaka merupakan suatu kebutuhan yang sangat penting bagi keberlangsungan perpustakaan. Secara etimologis preservasi berasal dari kata preserve atau to preserve yang dalam kamus Inggris-Indonesia yang disusun oleh Jhon M. Echols dan Hasan Sadily berarti pemeliharaan, penjagaan dan pengawetan. Selanjutnya, pengertian preservasi telah banyak dikemukakan oleh para ahli. Salah satu definisi preservasi dikemukakan oleh Ballofet dan Hille yaitu sebagai :

"Kegiatan yang mencakup kegiatan fisik dokumen dan informasi yang terkandung di dalamnya. Meliputi penyusunan kembali, penempatan ulang, dan penggunaan dari wadah atau tempat pelindung yang bertujuan memperluas akses untuk informasi yang kemungkinan bisa hilang karena halaman yang hilang, atau karena dokumen yang rusak". (Ballofet \& Hille, 2005)
Selanjutnya UNESCO tahun 1979 mengartikan istilah preservasi sebagai penanganan yang dihubungkan secara langsung dengan benda, kerusakan oleh udara lembab, faktor kimia, serangan mikroorganisme atau biologi yang harus dihentikan, untuk mencegah kerusakan lebih lanjut (Dureu \& Clements, 1992). Definisi lain dari preservasi dikemukakan dalam The Principles for The Preservation and conservation of Library Material yang disusun oleh J.M Dureau dan D.G.W Clements, preservasi mempunyai arti yang lebih luas lagi, yaitu mencakup unsur-unsur bagaimana pengelolaan keuangan, cara penyimpanan, tenaga/SDM, teknik dan metode yang digunakan untuk melestarikan informasi dalam bentuk fisik bahan pustaka. Dari pengertian diatas, preservasi dipahami sebagai bagian kegiatan pada perpustakaan, preservasi masuk pada bidang pelestarian bahan pustaka yang bertujuan untuk memelihara dan menjaga bahan pustaka dari kerusakan lebih lanjut dan dari kepunahan dan kerusakan yang mencakup unsur bagaimana pengelolaan keuangan, cara penyimpanan, tenaga, teknik dan metode yang digunakan, sehingga dapat memperpanjang usia bahan pustaka dan informasi yang ada di dalamnya.

\section{Tujuan dan Fungsi Preservasi}

Tujuan dan fungsi preservasi menurut UNESCO adalah untuk 
memperpanjang usia bahan pustaka dan informasi yang ada didalamnya. Sementara itu berdasarkan The Internasional Review Team for Conservation and Preservation serta J.M .Dureau dan D.G.W Clements dalam Principles for the preservasion and conservation of Library Materials" bahwa pelestarian bahan pustaka bertujuan melestarikan kandungan informasi ilmiah yang direkam dengan dialihkan pada media lain dan melestarikan bentuk fisik bahan pustaka sehingga dapat digunakan dalam bentuk seutuh mungkin. Preservasi bahan pustaka perlu dilakukan oleh perpustakaan. Hal ini bertujuan untuk melestarikan kandungan informasi yang ada pada bahan pustaka. Preservasi ini, meliputi pencegahan terhadap faktor-faktor perusak koleksi, perawatan fisik, seperti dengan menjilid ulang, melaminasi bahan pustaka atau mereproduksi bahan pustaka, seperti photokopi, alih bentuk (misalnya dari kertas ke microfilm, mikrofis atau digital).

Usaha Pencegahan dan Penanggulangan Kerusakan bahan Pustaka Tindakan Preventif (Pencegahan)

Pencegahan merupakan usaha untuk mengatasi suatu bencana sehingga resiko dari bencana tersebut dapat dihindari atau diperkecil (Perpustakaan Nasional, 1995: 96). Dari pengertian tersebut tindakan pencegahan merupakan usaha yang harus dilakukan untuk meminimalisir kerusakan yang diakibatkan oleh bencana. Usaha dalam melakukan pencegahan dari kerusakan bahan pustaka yang dilakukan sejak dini merupakan tindakan yang baik dan lebih tepat dari pada melakukan perbaikan bahan pustaka yang kondisinya telah parah. Secara preventif perpustakaan harus mempersiapkan secara matang kemungkinan yang akan terjadi. Mulai dari bangunan atau gedung yang harus diperhatikan, peralatan yang digunakan untuk menunjang sarana dan prasarana perpustakaan, suhu ruangan yang harus selalu dijaga agar koleksi perpustakaan tidak lembab, kebersihan ruangan perpustakaan yang harus diperhatikan, serta mengelola jajaran koleksi (shelving) dengan benar merupakan beberapa kegiatan preservasi secara preventif. Selain itu Perpustakaan juga harus menyediakan alat seperti alat pemadam untuk antisipasi terjadinya kebakaran. Pencegahan kerusakan bahan pustaka secara preventif menurut Martoatmodjo dalam buku Pelestarian Bahan Pustaka terutama bertujuan agar :

1) Kerusakan yang lebih hebat dapat dihindarkan. Koleksi yang dimakan oleh serangga atau binatang pengerat dapat diselamatkan.

2) Koleksi yang terkena penyakit, misalnya terkena jamur dapat 
diobati yang terkena kerusakan kecil dapat di perbaiki.

3) Koleksi yang masih baik dapat terhindar dari penyakit maupun kerusakan lainnya.

4) Kelestarian fisik bahan pustaka terjaga.

5) Kelestarian informasi yang terkandung dalam bahan pustaka tersebut dapat terjaga.

6) Pustakawan atau pegawai yang bekerja di perpustakaan sadar bahwa bahan pustaka bersifat rawan kerusakan.

7) Para pemakai, terdidik untuk berhati-hati dalam menggunakan buku serta ikut menjaga keselamatannya.

8) Semua pihak, baik petugas perpustakaan maupun pemakai perpustakaan selalu menjaga kebersihan lingkungan. (Martoatmodjo, 2009:3.2)

\section{Tindakan Kuratif (Penanggulangan)}

Sebagaimana dikemukakan diatas bahwa ada tiga faktor yang dapat menyebabkan kerusakan bahan pustaka, yaitu faktor fisika, kimia, biologi. Ketiga faktor tersebut dapat secara sendiri-sendiri merusak bahan pustaka. Dalam kegiatan pelestarian bahan pustaka, pengetahuan jenis bahan, penyebab kerusakan, dan tingkat kerusakannya sangat diperlukan untuk menetapkan bahan dan metoda penanganan yang tepat. Secara kuratif preservasi yang dilakukan oleh perpustakaan diantaranya dengan melakukan kegiatan-kegiatan

1) Fumigasi adalah salah satu kegiatan melestarikan bahan pustaka dengan cara mengasapi bahan pustaka agar jamur tidak tumbuh dengan melalui pembakaran atau penguapan zat kimia tertentu yang mengandung racun.

2) Kegiatan laminasi yaitu cara melapisi bahan pustaka dengan menggunakan kertas khusus agar bahan pustaka menjadi lebih awet.

3) Kegiatan enkapsulasi adalah salah satu cara melindungi kertas dari kerusakan dengan cara menempatkan setiap lembar kertas diantara dua plastik transparan, kemudian pinggiran plastik tersebut dilem sehingga bahan pustaka tidak terlepas. Bahan pustaka yang di enkapsulasi biasanya berupa lembaranlembaran seperti naskah kuno.

4) Penjilidan ulang, penjilidan pada dasarnya merupakan kegiatan menghimpun atau menggabungkan lembaran-lembaran lepas sehingga menjadi satu, yang dilindungi oleh sampul. 


\section{METODE PENELITIAN}

Metode yang digunakan dalam penelitian ini adalah metode kualitatif. Penelitian Kualitatif menurut Lexy J. Moleong dalam buku Metodologi Penelitian Kualitatif mengemukakan bahwa Penelitian Kualitatif adalah "penelitian yang menghasilkan prosedur analisis yang tidak menggunakan prosedur analisis statistik atau cara kuantifikasi lainnya”. (Moleong, 2010: 6). Penelitian kuantitatif didasarkan pada upaya membangun pandangan mereka yang diteliti yang rinci, dibentuk dengan katakata, gambaran holistik dan rumit. Selanjutnya Moleong mengemukakan bahwa:

"Penelitian kualitatif adalah penelitian yang bermaksud untuk memahami fenomena tentang apa yang dialami oleh subyek penelitian, misalnya perilaku, persepsi, motivasi, tindakan dll secara holistik dan dengan cara deskripsi dalam bentuk kata-kata dan bahasa, pada suatu konteks khusus yang alamiah dan dengan memanfaatkan berbagai metode alamiah.” (Moleong, 2010:6).

Menurut pengertian diatas dapat dipahami bahwa penelitian kualitatif lebih menekankan cara deskripsi dalam mengungkapkan kejadian yang dialami oleh subyek penelitian. Dengan demikian penelitian kualitatif akan lebih dapat mengungkapkan proses pemecahan permasalahan yang diteliti. Hal ini sesuai dengan fungsi dan pemanfaatan penelitian kualitatif yaitu "dimanfaatkan oleh peneliti yang ingin meneliti sesuatu dari segi prosesnya" (Moleong, 2009:7). Pada penelitian ini yang menjadi fokus adalah preservasi bahan pustaka yang disebabkan gempa bumi di Perpustakaan SD Negeri Kudang Kecamatan Manonjaya Kabupaten Tasikmalaya. Adapun untuk menjabarkan fokus penelitian tersebut dilakukan melalui proses preservasi koleksi sebelum, saat kejadian dan setelah kejadian bencana alam gempa bumi yang dilaksanakan di Perpustakaan SD Negeri Kudang Kecamatan Manonjaya Kabupaten Tasikmalaya. Melalui pendekatan kualitatif ini, diharapkan dapat memperoleh data yang lebih lengkap untuk memahami fenomena yang terjadi, melalui observasi/pengamatan langsung, wawancara, studi kepustakaan, dll.

\section{HASIL DAN PEMBAHASAN}

Sebagaimana dikemukakan di atas, bencana alam Gempa Bumi Tasikmalaya Tahun 2009 juga menimbulkan dampak kerusakan pada SDN Kudang. Dari dampak kerusakan tersebut, bangunan perpustakaan merupakan salah satu prasarana yang mengalami kerusakan cukup parah, hal ini disebabkan karena usia bangunan yang 
sudah cukup tua yaitu dibangun pada sekitar tahun 1980, sehingga banyak bagian yang sudah lapuk. Kerusakan yang cukup parah ini juga salah satunya disebabkan oleh karena struktur bangunan yang dibuat tanpa tiang beton sehingga tidak tahan gempa. Kerusakan bangunan perpustakaan ini, juga menyebabkan sarana dan prasarana yang ada di perpustakaan turut mengalami kerusakan yang cukup parah. Dari informasi yang diperoleh melalui hasil wawancara dengan nara sumber, kerusakan sarana dan prasarana perpustakaan berupa rusaknya bahan pustaka, rak penyimpanan, meja dan kursi baca serta sarana dan prasarana yang lainnya.

\section{Preservasi Koleksi Sebelum Kejadian}

\section{Gempa Bumi}

Pencegahan merupakan usaha yang pertama harus dilakukan dalam preservasi koleksi. Dengan pencegahan, maka resiko yang ditimbulkan oleh bencana dapat diminimalisir sehingga koleksi bahan pustaka bisa diselamatkan. Salah satu upaya pencegahan adalah perencanaan. Sebelum terjadinya gempa bumi Tasikmalaya Tahun 2009 di Perpustakaan SDN Kudang secara formal tidak terdapat tim. Hal ini disebabkan Perpustakaan SDN Kudang sebagai perpustakaan sekolah belum memiliki pustakawan yang secara khusus menangani perpustakaan. Pengelolaan perpustakaan masih mengandalkan para pendidik/guru sehingga untuk pembentukan tim sebagaimana diatas belum dapat direalisasikan.

Dengan kondisi seperti ini, maka perencanaan penanggulangan bencana di SDN Kudang tidak akan dapat dilaksanakan dengan baik yang pada akhirnya preservasi tidak akan dapat dilaksanakan secara optimal. Bangunan perpustakaan SDN Kudang, merupakan bangunan lama yang dibangun pada Tahun 1980-an, yang dibangun dengan struktur bangunan batu bata tanpa dilengkapi dengan tiang beton bertulang. Begitupun pondasi bangunan terdiri dari pasangan batu tanpa diikat dengan beton bertulang. Hal tersebut mengakibatkan kerusakan yang dialami oleh bangunan perpustakaan SDN Kudang ketika terjadi Gempa Bumi Tasikmalaya Tahun 2009 cukup berat, dimana bangunan tidak dapat menahan goncangan dan mengalami ambruk di bagian atap dan dinding. Merencanakan tata ruang perpustakaan sangat diperlukan dalam mengatur sebuat ruang perpustakaan. Hal ini diperlukan untuk memberikan kenyamanan bagi petugas perpustakaan dan pengguna perpustakaan serta dapat mempermudah proses evakuasi pada saat terjadi bencana sehingga dapat meminimalisir kerusakan bahan pustaka dan jatuhnya korban.

Dalam hal penataan ruang, bangunan perpustakaan SDN Kudang secara umum 
telah dilaksanakan dengan baik, dimana lemari berada di samping ruangan dan meja baca serta rak bumi berada ditengah ruangan. Hal tersebut memberikan ruang yang cukup bagi pengguna perpustakaan dalam melakukan aktivitas. Penataan yang baik ini juga akan memudahkan proses evakuasi jika terjadi bencana. Sebagai upaya penyelamatan koleksi bahan pustaka dari kerusakan yang lebih parah, maka diperlukan perencanaan persiapan lokasi pemindahan koleksi perpustakaan yang lebih aman jika terjadi kerusakan gedung perpustakaan akibat bencana. Dalam hal Perencanaan persiapan lokasi pemindahan koleksi perpustakaan di perpustakaan SDN Kudang pada dasarnya belum mempunyai perencanaan lokasi sebagai tempat penyimpanan koleksi bahan pustaka jiga terjadi bencana. Pihak sekolah tidak memiliki ruang yang cukup sebagai cadangan ruang sebagai tempat evakuasi baik dari segi sarana dan prasarana jika terjadi bencana.

Persiapan alat pemadam kebakaran diperlukan karena tidak jarang terjadi kebakaran pasca bencana gempa bumi, sedangkan penyediaan alat pertolongan pertama berupa peralatan penggalian, dan peralatan perlindungan lainnya diperlukan sebagai antisipasi akibat gempa bumi. Dalam hal ini Perpustakaan SDN Kudang tidak dilengkapi dengan alat pemadam kebakaran dan alat pertolongan pertama, sehingga apabila terjadi kebakaran akan sangat susah mencari alat untuk memadamkan api. Pelatihan dan pendidikan dasar penanggulangan bencana sangat diperlukan bagi para petugas yang mengelola sebuah tempat pelayanan, termasuk petugas di perpustakaan. Dengan adanya pelatihan dan pendidikan diharapkan para petugas memiliki pengetahuan dan keahlian dalam penanggulangan bencana termasuk penanggulangan dampak dari bencana. Petugas pengelola perpustakaan SDN Kudang belum pernah dibekali dengan pelatihan atau pendidikan tentang penanggulangan bencana.

\section{Preservasi Koleksi Pada Saat Kejadian}

\section{Gempa Bumi}

Bencana seperti gempa memang tidak pernah diharapkan, akan tetapi sering terjadi sepanjang sejarah. Respon yang baik oleh berbagai pihak dalam menanggapi gempa sangat dibutuhkan untuk penyelamatan jiwa manusia dan koleksi perpustakaan. Dalam hal preservasi pada saat kejadian gempa bumi, gempa bumi Tasikmalaya Tahun 2009 terjadi pada pukul 14:55:21 WIB, pada saat tersebut kegiatan belajar mengajar di SDN Kudang sudah selesai, sehingga tidak ada orang yang berada di lokasi. Selanjutnya Evakuasi barang dan koleksi dilaksanakan 1 (satu) hari setelah kejadian gempa dengan memindahkan barang dan koleksi ke tempat 
yang lebih aman, yaitu kedalam ruangan kelas yang kerusakannya tidak cukup parah.

Preservasi Koleksi Sesudah Kejadian

\section{Gempa Bumi}

Upaya penyelamatan yang pertama dilakukan paska kejadian gempa bumi adalah dengan cara mengevakuasi bahan pustaka yang rusak terkena bencana dengan memindahkannya ke tempat yang lebih aman. Dalam hal ini upaya evakuasi yang dilakukan oleh SDN Kudang untuk menyelamatkan bahan bustaka adalah dengan memindahkan bahan pustaka yang terkena bencana ke dalam ruangan kelas yang tidak mengalamai kerusakan sehingga bahan pustaka dapat terhindar dari kerusakan yang lebih parah. Selain itu, mengidentifikasi jenis bahan pustaka yang mengalami kerusakan, jumlah dan tingkat kerusakannya sangat diperlukan untuk proses preservasi bahan pustaka selanjutnya. Identifikasi dilakukan untuk mempermudah penanganan bahan pustaka yang mengalami kerusakan dengan memilah jenis dan tingkat keruskan, sehingga dapat ditentukan proses perbaikan apa yang akan dilakukan terhadap bahan pustaka tersebut.

Hasil identifikasi yang dilakukan oleh perpustakaan SDN Kudang terhadap kerusakan yang ditimbulkan akibat bencana gempa bumi Tasikmalaya Tahun 2009 khususnya kerusakan bahan pustaka adalah rusak berat sebanyak 1.054 eksemplar terdiri dari 998 eksemplar buku dan 56 eksemplar majalah, rusak sedang sebanyak 294 eksemplar yang terdiri dari 274 eksempar buku dan 20 eksemplar majalah serta rusak ringan sebanyak 114 eksempalar yang terdiri dari 103 eksempalar buku dan 11 eksemplar majalah. Sebagaimana dikemukakan di atas dari hasil identifikasi, maka bahan pustaka yang mengalami kerusakan dipilah sesuai dengan tingkat dan jenis kerusakan. Hal ini bertujuan untuk memepermudah dalam menentukan tindakan perbaikan apa yang akan dilakukan terhadap bahan pustaka tersebut.

Dari hasil penelitian paska terjadinya bencana alam gempa bumi Tasikmalaya Tahun 2009 di perpustakaan SDN Kudang terdapat sebanyak 1.375 eksempar buku dan sebanyak 81 eksemplar majalah yang mengalami kerusakan. Bahan pustaka yang mengalami kerusakan tersebut setelah diidentifikasi kemudian dipilah menurut tingkat kerusakannya. Setelah dilakukan identifikasi dan memilah bahan pustaka yang terkena bencana sesuai tingkat dan jenis kerusakan, maka bahan pustaka tersebut harus dilindungi agar tidak terjadi kerusakan lebih lanjut yang pada akhirnya bahan pustaka tersebut tidak dapat diselamatkan. Dalam hal perlindungan, maka bahan pustaka hasil identifikasi dan pemilahan harus ditempatkan pada ruangan yang lebih aman sehingga terhindar dari 
kerusakan yang lebih parah. Hasil penelitian di perpustakaan SDN Kudang, bahan pustaka yang telah diidentifikasi dan dipilah nkemudian ditempatkan pada satu ruangan yang aman yaitu didalam ruang Kepala Sekolah sehingga dapat terlindung dari kerusakan yang lebih parah. Bahan pustaka yang memungkinkan untuk di preservasi adalah bahan pustaka yang mengalami kerusakan sedang dan ringan. Dari kondisi tersebut, maka dalam menentukan kebutuhan bahan harus disesuaikan dengan kebutuhan proses preservasi kerusakan bahan pustaka tersebut.

Identifikasi bahan yang dilaksanakan di SDN Kudang hanya terbatas pada bahan yang sifatnya sederhana diantaranya adalah kuas, spon/busa, lem, solatif, kertas dan lain-lain. Proses utama dari preservasi paska bencana adalah pelaksanaan penyelamatan bahan pustaka sesuai tingkat dan jenis kerusakan. Sebagaimana hasil identifikasi, bahan pustaka yang memungkinkan untuk dilakukan proses preservasi adalah kerusakan sedang dan ringan. Adapun proses preservasi yang dapat dilaksanakan antara lain berupa :

1. Pembersihan pembersihan dilakukan terhadap bahan pustaka yang kotor akibat debu dan kotoran lainnya.

2. Pengencangan Sampul dilakukan terhadap bahan pustaka yang mengalami sampul kendur. Kerusakan sampul kendur dialami oleh bahan pustaka berupa buku dan majalah yang sampulnya menggunakan teknik jahit dan hekter.

3. Menambal dilakukan untuk menutup lubang-lubang pada kertas atau dilakukan terhadap bahan pustaka yang mengalami kerusakan berupa sobek.

4. Menyambung dilakukan untuk menyatukan kembali kertas yang sobek dan terlepas dari bahan pustaka.

5. Penjilidan ulang dilakukan terhadap baha pustaka yang mengalami kerusakan sedang berupa kerusakan pada sampul yaitu sampul yang lepas dan isi buku yang lepas.

Bahan pustaka yang telah melalui proses perbaikan dan penyelamatan, maka bahan pustaka tersebut diidentifikasi untuk kemudian dipilah sesuai dengan klasifikasi. Bahan pustaka yang telah melalui proses klasifikasi ini kemudian ditempatkan kembali untuk dapat digunakan oleh pemustaka. Dalam hal ini bahan pustaka pebaikan dan penyelamatan di SDN Kudang ditempatkan pada lemari di ruangan kelas yang difungsikan sebagai ruang perpustakaan sementara.

\section{SIMPULAN}

Perpustakaan SDN Kudang secara formal tidak memiliki tim tentang perencanaan pencegahan bencana alam. Hal 
ini disebabkan perpustakaan SDN Kudang sebagai perpustakaan sekolah belum memiliki pustakawan yang secara khusus menangani perpustakaan. Pengelolaan perpustakaan masih mengandalkan para pendidik/guru sehingga untuk pembentukan tim sebagaimana diatas belum dapat direalisasikan.

Gempa Bumi Jawa Barat 2009 terjadi pada hari Rabu tanggal 2 September 2009 pada pukul 14:55:21 WIB, dimana pada saat tersebut kegiatan belajar mengajar di SDN Kudang sudah selesai, sehingga tidak ada orang yang berada di lokasi. Dengan kondisi tersebut preservasi pada saat kejadian gempa bumi hanya dilakukan pada barangbarang yang beresiko rusak lebih parah.

Upaya penyelamatan bahan pustaka yang dilaksanakan di SDN Kudang pasca kejadian gempa bumi 2009 adalah dengan cara mengevakuasi bahan pustaka yang terkena bencana dan memindahkan ke tempat yang lebih aman yaitu ke dalam ruangan kelas yang tidak mengalamai kerusakan sehingga bahan pustaka dapat terhindar dari kerusakan yang lebih parah, kemudian mengidentifikasi jenis bahan pustaka yang mengalami kerusakan, jumlah dan tingkat kerusakannya akibat bencana gempa bumi, dan memilah bahan pustaka yang terkena bencana sesuai tingkat dan jenis kerusakan. Setelah diidentifikasi, kemudian dilakukan pembersihan, pengencangan sampul dan penjilidan ulang.

\section{DAFTAR PUSTAKA}

Ballofet, N. and Hille, J. (2005). Preservation and conservation for libraries and archives. Chicago: American Library Association.

Basuki, Sulistyo. (2010). Pengantar ilmu perpustakaan. Jakarta: Universitas Terbuka.

Dureau, J. M. and Clements, D.G.W. (1992). Dasar-dasar Pelestarian dan Pengawetan Bahan Pustaka. Jakarta: Perpustakaan Nasional RI. Martoatmodjo, K. (2009). Pelayanan Bahan Pustaka, Jakarta: Universitas Terbuka.

Moleong, L. J. (2010). Metodologi Penelitian Kualitatif. Bandung: Remaja Rosdakarya.

Sitepu, A., Armansyah, C., Saary, R., \& Rahayu, R. (2012). Kesiapsiagaan dalam mengantisipasi bencana di perpustakaan dan pusat arsip. Baca: Jurnal Dokumentasi Dan Informasi, 30(1), 1-13.

Sugiharto, D. (2010). Penyelamatan informasi dokumen/arsip di era teknologi digital. Baca: Jurnal Dokumentasi Dan Informasi, 31(1), 51-64. 
